\title{
Right To Education of The Third Gender of Bangladesh: An overview
}

\author{
Md. Akramul Islam ${ }^{1}$
}

\begin{abstract}
The eunuchs who are also known as third gender are far and beyond the realm of education in Bangladesh. The term third gender is popularly known as Hijras in Bangladesh. They are totally isolated and marginalized people in our society. However, we have observed that almost always these groups of people are getting underprivileged from their rights including right to education. The actuality of their existence is still a secret and their omnipresence in the Bangladesh society is manifest. They have always remained a fundamental part of the Bangladeshi society from ancient time. But unfortunately their present state of existence has been reduced to wretched poverty, illiteracy, hatred and mockery. The Hijras are still living in the shadow of rejection from every basic right to equality and education. The main object of this article is to focus on the issue that how far our education system is still incompatible for eunuch people of our country. In most of the cases they become the topic for exploration and research for their strange appearances. The world at large has forgotten that they are also human beings and have equal rights like everybody. The negative attitude of the people and their isolation from the society has left them with no prospect. The government has only given them the right to vote but they face a desolate future without any access to education. This article took an attempt also to focal point on the steps which might be taken by the apposite authority for their betterment as well as to ensure their right to education. Consequently, to ensure the implementation of human rights as well as to utilize the internal capacities of the hijras of our country we should go forward effectively as early as achievable.
\end{abstract}

Key words: Educational right, international instrument, human rights, recognition, working atmosphere

\section{INTRODUCTION}

The concepts of human rights and equal rights have been an issue of the 20th century. However, hijras of Bangladesh commonly known as human beings who are neither male nor female. Most of the people regard them as person incapable of sexual sensation. Right to education is still a fundamental principle of state policy of our country. Truth is that many people of our country are deprived partially of right to education. But the matter of regret is that the hijra communities of this country are entirely excluded from this right. In Bangladesh, the spirit of the Constitution is to make certain the fortification of fundamental rights of every citizen. Article 27 of the Constitution provides that all citizens are equal before law and are entitled to equal protection of law. Article 28(1) further provides that the State shall not discriminate against any citizen on grounds of religion, race, caste or sex (Kelly, 2009). So, as a citizen eunuch people are definitely entitled to get educational right like others. The main shortcoming of eunuch people is, they cannot produce baby. Only because of this incapability they are deprived from educational facilities \& ultimately they cannot find any impressive occupation in the society. Eunuchs traditionally earn their living by collecting alms and receiving payment for performances at weddings, births and festivals. The unpleasant and undesirable truth is that, eunuchs are presumed outsider community in our society though they born in our society. They are outsider because in our society in every sector people are identified as male or female and they have social recognition and enjoying all the facilities like educational, cultural, economic, political participatory right etc. inter alia all fundamental rights, as a result of which they can enforce their rights and demand. But eunuch is not fall into any of those categories and deprives of most of the important citizen's right which are available for the ordinary people in the society specially the right to education which can help them to be a human resource of the society and establish themselves; as a result they remain marginalized in the society. They cannot muddle up recurrently with others in the society. They live in their own communities. Hijras are treated as bits and pieces of mockery or sometimes looked at with trepidation. In an interview in one of the leading TV channels, a journalist asked a few eunuchs what gender they would want to be born as in their next lifetime. One of them said male, the other said female, while another said male or female, but not something in between (http://www.dhakatribune.com). Even eunuchs are not safe in sex trade. They are forced to have unprotected sex with clients, local influential persons, and police free of charge. Even after their death, as they did not belong to either the male or female gender, burial ceremonies create problem in society, how unfortunate!

\begin{tabular}{lcr}
\hline${ }^{1}$ Lecturer, Department of Law, Northern University Bangladesh & \\
\hline DOI: $10.9790 / 0837-2109072934$ & www.iosrjournals.org & $29 \mid$ Page
\end{tabular}




\section{OBJECTIVES OF THE STUDY:}

The main purpose of this study is to create consciousness among the common people about the rights of the third gender to education and to point up on the issue of creating a responsive environment to ensure their right to education.

\section{METHODOLOGY OF THE STUDY:}

In this study data were collected from both primary and secondary sources. Mostly this article is written on the basis of qualitative method. This research has been done on the basis of objective approach based on the obtainable literature \& national and international papers as replica breakdown or random sample collection was not possible owing to the unwillingness of the respondent to endow with correct data.

\section{LITERATURE REVIEW:}

In order to prepare this article I went through a good number of documents and articles which deals mostly with the problems of the people of third gender regarding their disabilities \& the inevitability to provide them to stay somewhere in the society. In so far as I am concerned there is no article written on the right to education of third gender people in Bangladesh. I have tried to follow the deductive loom in my research for coming to a termination.

\section{RIGHT TO EDUCATION ON THE BASIS OF INTERNATIONAL INSTRUMENTS:}

The right to education for the eunuch people is the human rights issue. In Europe, Article 2 of the first Protocol of 20 March 1952 to the European Convention on Human Rights states that the right to education is recognized as a human right and is understood to inaugurate an entitlement to education. According to the International Covenant on Economic, Social and Cultural Rights, the right to education includes the right to free, compulsory primary education for all, an obligation to develop secondary education reachable to all in particular by the enlightened introduction of free secondary education, as well as an obligation to develop justifiable access to higher education in particular by the reformist introduction of free higher education. The right to education also includes a responsibility to provide basic education for individuals who have not completed primary education (http://emmashopebook.com). In addition to this access to education provisions, the right to education incorporates also the obligation to eliminate discrimination at all levels of the educational system, to set minimum standards and to improve quality. The European Court of Human Rights in Strasbourg has applied this norm for example in the Belgian linguistic case. The right to education is a law in Article 26 of the Universal Declaration of Human Rights and Articles 13 and 14 of the International Covenant on Economic, Social and Cultural Rights. The right to education has been reaffirmed in the 1960 UNESCO Convention against Discrimination in Education, the 1981 Convention on the Elimination of All Forms of Discrimination Against Women, and the 2006 Convention on the Rights of Persons with Disabilities. Article 10 of the European Social Charter guarantees the right to vocational education (http: //en.wikipedia.org).

\section{HUMAN RIGHTS OF THE HIJRAS (THIRD GENDER):}

Right to education is one of the basic rights of all human beings. Nevertheless we have observed that almost always different classes of people are getting deprived of the right to education. Eunuch people are also going to that class of people. The International Human Rights Day comes and goes every year. Human Rights activists talk of torture of under trials in police custody. They talk about human beings being subjected to medical experimentation without their mindful knowledge. They thrash out socially relevant subjects like violence against women, child abuse, trafficking or exploitation of child labor in countries. But the lot of the community of eunuchs is largely disregarded even by their own. It is also true that at every stage of their existence, their rights to live and work like normal human beings are violated with impunity (Ghiselin, 1969).

The term Hijra, which, is of Urdu origin and the masculine gender, has the primary meaning of hermaphrodite. It is usually translated as eunuch. In our country Hijra means those who are anatomically true hermaphrodite and a special character distinguished a class of individuals from both men and women and ascribed them with a constellation of traits comparable to those personas used to define other gender. Bangladesh alone is anticipated to be a home to about ten thousand eunuch according to the survey conducted by the Ministry of Social Welfare, but the number can be 10 times higher. They live in germ-infested conditions fraught with poverty and internal cacophony. While at one hand they are unaccepted in a society of "normal" beings, they also live in discord among themselves only with the hope to survive in a slightly better condition than the other sleeping next to 
them (Herculine and Michel, 1980). The kind of life that is led by this group, especially in Bangladesh, is blemished with more than just. Hijras are socially excluded, living on the fringes of society, harassed by the police and maltreated by the public. Though most of them are involved in singing and dancing at weddings or child birth as a part of their traditional Badhai culture but few of them are in begging and sex trade. Violence against hijra, more than ever hijra sex workers, is often brutal, and occurs in public spaces, police stations, prisons, and their homes. They face extreme discrimination in health, housing, education, employment, immigration, law, and any bureaucracy that is unable to place them into male or female gender categories (http://www.dhakatribune.com).

\section{HOW THE CONCEPT OF THIRD GENDER DEVELOPED:}

The term "third gender" describes individuals who are categorized as neither man nor woman. Although nothing seems more natural to us than those human beings who are divided into two genders, masculine and feminine. However, the world is unhurriedly moving towards the formal appreciation of the existence of a third gender. As reported by the Global Issues Section in the Office of the United Nations High Commissioner for Human Rights, the rights of transgender people, particularly to say, their own identity and access to health, education, work, housing and other rights are being all the time more widely recognized ( Meese and Parker, 1989). To be noted, there has long been a folklore of a third gender in the region of South Asia, known as hijras, and neighbours to Bangladesh particularly India, Nepal and Pakistan have by now given the recognition to the third gender people.Following a Supreme Court landmark decision against gender uniqueness discrimination in 2007, Nepal is believed to have become the world's first country to include a third gender option on its census forms, which it initiated in 2011 (Wijngaard and Marianne, 1997). The country has led the way in South Asia, also introducing a third gender category on its passports in 2012. In 2009, local police had allegedly attacked, robbed and raped eight hijra wedding dancers near Islamabad, Pakistan. That traumatic event led Muhammed Aslam Khaki to file a private case in the country's Supreme Court, asking to recognize hijras as a third gender. In December, 2009, the Supreme Court of Pakistan ordered that the Government shall officially recognize a separate gender for Pakistan's hijra community, which includes transgendered people, transvestites, and eunuchs. In addition, the Hon'ble Chief Justice of Pakistan issued a warning that the hijras' rights of inheritance would be enforced and that police harassment would not be permitted. He ordered the National Database and Registration Authority to issue national identity cards with a "third gender" category for non-binary citizens (Money and Hampson, 2002). . It may be noted here that the Supreme Court of Pakistan earlier in June, 2009 ordered the Government to set up a Commission to conduct a census of transgender community. India has about two million transgender people who have been strained to choose either male or female as their gender in most public spheres. In 2009, India's Election Commission took a first step by allowing transgender to choose their gender as "other" on ballot forms. India's Supreme Court has recognized transgender people as a third gender, in a landmark case of "National Legal Services Authority v Union of India and Others" in April 2014. "Recognition of transgender as a third gender is not a social or medical issue but a human rights issue," Justice KS Radhakrishnan, said in his judgment. In its landmark ruling, the Supreme Court declared that "it is the right of every human being to choose their gender," granting formal, legal recognition to Indians who identify as neither male nor female, or those who identify as transgender women, known as hijra (Warner, 1988). In $11^{\text {th }}$ November, 2013, the policy decision to legitimately recognize the hijras or transgender as a separate gender or third sex in our community was approved in the Government's Cabinet Meeting Presided over by the then Hon'ble Prime Minister of Bangladesh. This decision will allow them to identify their gender as hijra when personal information will be required to be furnished and their passports too would state their gender as hijra. The transgender community is now enlisted as voters in Bangladesh. They have had the right to vote since 2009. However, some legislative or judicial amplification is still essential for there to secure the fundamental rights of the transgender community in our country.

If these new legal advancements regarding the status of Hijras are upheld, they may offer hope that a more progressive human rights movement is possible in other Muslim dominated countries. With reference to the Quran, "As long as Hijras are human...the objective of Shariah, which is to do justice to all humans, definitely applies to them" (Serena,1990). In point of fact, acknowledging Hijra's as third gender is a landmark decision made by the government of Bangladesh, but in reality they are not getting mentionable change and still deprive of right to education resulting not getting employment opportunity. So what is the ultimate result of the so called recognition of Hijra community? After the government announcement, we are still waiting for a specific law to be enacted to cover third gender people's rights. The government must make sure that the third genders have access to educational amenities, job opportunities, social dignity, economic empowerment etc. The government should also treat transgender as "socially and economically minority," to facilitate them to get quotas in jobs and education (http://www.thedailystar.net). 
VIII. THE NECESSITY OF EDUCATION FOR HIJRAS (THIRD GENDER) :

Education is a social course of action through which peoples' knowledge, propensity, efficiency, moral strength and character are cropped up. Global and Local Commitment to Education Access to basic education is now the right of all human beings and it is the key to most of the nation's progression objectives. "Everyone has the right to education", says Article 26(1) of the 1948 Universal Declaration of Human Rights. Declaration of the Rights of the Child proclaimed by the UN General Assembly in 1959 states, 'the child is entitled to receive education, which shall be free and compulsory, at least in the elementary stages.' From the Geneva Declaration of the Rights of the Child of 1924 to the United Nations Convention on the Rights of the Child of 1989, all international declarations and covenants on rights of the child acknowledge children's right to education (Emma, 1996). The same is echoed in the Dakar Forum on Education for All (EFA) and Millennium Development Goals in 2000. Bangladesh has been trying unremittingly to uphold the cause of education for all since its emergence as an independent country. Article 17 of the Constitution of Bangladesh stipulates that primary education shall be the delicacy of the State. To bear this responsibility primary education in Bangladesh underwent a great deal of changes and development during the last few years. Bangladesh is a signatory to the world declaration on education for all held at Jomtien, Thailand in March 1990. Bangladesh is also a signatory to the summit of 9 high populous countries held in Delhi. So, as human being eunuch people can claim educational right. But practically they are the ignored class of people. In Bangladesh, the spirit of the Constitution is to ensure the protection of fundamental rights of every citizen. Article 27 of the Constitution provides that all citizens are equal before law and are entitled to equal protection of law. Article 28(1) further provides that the State shall not discriminate against any citizen on grounds of religion, race, caste or sex. From statistics, it appears that there are at least 10,000 hijras in Bangladesh and they are being denied their rights in various sectors including education because of being a marginal group which is inconsistence with the constitution.

In consequence human rights violations in contrast to them take place day-to-day. The right not to be discriminated against in the enjoyment of human and fundamental rights, as a matter of fact, is also desecrated when persons whose states are suggestively different fail to be treated differently without fair-minded justification. Persons who are eunuch should not be neither painstaking nor treated as a population that is not able to accomplish goals such as independence, self-determination and dignity, but as human beings with unique, unlimited potential. The old negative perspective accentuates disability, considers disabled persons as objects of assistance and provides facilities made to order to impairments. This includes failing to provide persons who are eunuch the positive actions they need in order to have access to proper services and facilities ensuring early, life-long, effective education, vocational training, habilitation and health programs (Johanna, 2005). This shortage of proper facilities and services rule out them to have access to work, leisure, sport and cultural activities in the mainstream.

Eunuch people are at a standstill a neglected disease in Bangladesh. Many parents don't want to face the realism that their children are eunuch. They often feel infamy to disclose it to others in the early stages. They feel agitated about bringing their eunuch children to social gatherings, thinking that it might be worrying for others (Gedge, 2009). If our government can take initiatives for a cost- effective programme for eunuch people many families will be gratifying. We find that they are often physically abused. Nothing is going to happen overnight. These children may improve and live a close to normal life if apt intervention and proper training are imparted in time. Though we have many organizations in Bangladesh working with various fields of infirmity, there is scarcely any quality institute developed exclusively for the eunuch people. The problem further is provoked with the unavailability of centers to train trainers or teachers to work with eunuch people. Similarly, there is no facility obtainable for the training or motivation of parents or caregivers of eunuch children. Parents, relatives and teachers of eunuch children should be more patient in raising such child. Relatives and family members should show respect to the suffering of such parents. We have to enlarge a strong program through government and NGO collaboration to ensure a useful come within reach of to help these classes of people and their families. If they are properly trained, they can to a large extent contribute, instead of becoming a burden, to others. Education is the fundamental need of eunuch people while state is responsible for creating affable educational atmosphere for that kind of people who are burden for family.

The right to education is crucial to allow eunuch persons to develop to the full of their in the near future and be included in the community. States must guarantee an effective exercise of their right to education in mainstream schools, and/or in special schools only if inclusion in mainstream schools is not possible and if this decision is agreed with the parents. This also means that apart from teaching academic skills, education of eunuch people must include grounding for an independent life, adaptive behaviors and social skills. Adult education should provide the utmost range of opportunities and include not only special education or participation in mainstream adult educational programs but also training in basic skills, self-management, living skills, at all ages. Lunch discrimination gratis educational system to ensure basic rights initiatives to introduce formal, informal and technical educations \& create quota system to enroll hijra in educational institutes as well as for higher studies in all Universities (Mckeown, 1988). 


\section{WORKING ATMOSPHERE:}

Hijras are also human beings, they have lives, they need food, shelter, clothe, education and job to stay alive in the world like other men and women, despite being the fact that hjras are human being, but they are starved of their every right-as social taboos and discrimination made them untouchable, fearsome and funny (Jarne and Auld 2006). Though they are recognized as third gender in Bangladesh, they do not have educational facilities. They are rundown from educational facilities. Due to lack of educational knowledge they do not have a proper source of income and usually resort to begging or waitressing. Some of the little fortunate ones find a place in the film or the fashion industry, but their chipping in these fields only leads to further humiliation. In most cases, they are sent away from their homes right after birth, and receive no ceremonial education. As such, they earn a living by harassing people in various ways and collecting money from them, formerly known as "chadabaji," along with prostitution (The Daily Star, August, 2015).

Another problem that makes matters worse is the mythical belief that eunuchs are bestowed with paranormal powers that are capable of cursing "normal" beings into a fate of misery. Taking advantage of this myth eunuchs in Bangladesh take to the streets, buses, trains, and even to wedding halls demanding huge sum of money in exchange for blessings; sometimes even resorting to violence when their demands are not met. Long before they are believed to bring good luck to newborn children. During the time of Muslim rule in the Indian subcontinent, they were used as body guards for royalty and holy buildings. Wretchedly, this is a far cry from the current social standing simply having the new and progressive legislation on paper is not enough. In Bangladesh, the old respected role of blessing newlyweds and newborns has been kept alive in some traditional rural communities and in old Dhaka, in the midst of the oldest, indigenous families. Today the financial gains from such modes of income are poor indeed, and urban Hijra's have increasingly become sex workers

The eunuch people claimed helplessness of getting a mainstream job due to lack of education, 'unusual' nonconforming lifestyle unacceptable for the working environment. Because of their feminine gesture, do not have way in to any job. They always kicked out from the job on the grounds of 'destroying' the job environment." Some got jobs but eventually were dismissed when employers learned of their feminine attitudes. In some cases, many eunuchs were abused verbally, physically, and sexually at workplaces for which they never received any evenhandedness they rather lost the job because the employers wanted to 'save the workplace from sexual contamination'. One hijra depicted 'her' condition when 'she' attempted work in a garment factory: I have worked in a garment factory for about a year. I could not even go to the toilet, as I was scared that the boys would go there to see me. They always tried to have sex with me. When there was a night shift, the threat was higher. Once my supervisor forced me to have sex with him, and I had no choice to but to do it. But when it became public, my job was dismissed, as if it was my fault (http://www.dhakatribune.com).

If not properly educated, how can we expect them to earn a decent income any other way? Have we ever offered them jobs or made any other effort to help them? This group is one that is rejected firstly by their parents who give birth to them, and then by the entire society. Not only in Bangladesh but also in the world at large, in spite of having a large number of domestic Human Right documents before 1945 and even after 1945 International concept on Human right establish and large number of International Human Right documents like UDHR, ICCPR, ICESCR etc. from top to bottom failed to ensure and establish the human rights specially the right to education of the eunuch and till today they are deprive of education as a result of which this community remains socially excluded, living on the periphery of society, under duress by the police and battered by the public, and that is why it is the high time to ensure the educational right by giving special attention and concentration to ensure the same for them because there is no room for discrimination in the law or constitution. It is a matter of hope that already the Government of Bangladesh recognizes them as third gender and gives the voting right. Now educational right must also be ensured by the government by taking special measures and initiatives for educational right for the susceptible and rob group of people.

\section{FINDINGS}

The finding of this research shows that eunuch people are very few in number. Apposite and forthcoming atmosphere can make eunuch people positive feature for the country. In this research eunuch people were the independent variables and absence of proper education system was the dependent variables at the back the violation of the right to education of the eunuch people. We are condemning a group of people, treating them worse than we treat convicted felons, murderers, rapists, psychopaths. We must begin thinking of it this way. We must stop. We must stop the way we think about eunuch. We must stop oversimplifying; we must stop applying our neurotypical thought processes to eunuch people. We must stop with our rulebooks. Unquestionably it is the conscientiousness of the state to create such education system which can ensure the right to education for the eunuch people. Moreover, the right to education for the eunuch people has been despondently overlooked. That has to change. Education is surely one of the many solutions that the government can take to. Setting up institutions that cater to their educational requirements will surely be one fruitful step towards curbing discrimination against this group; rigorous enforcement of reservation laws in government 
services is another. Immediate actions need to be taken to get equal opportunity in education, treatment and employment and introduction of quotas in educational institutes, public services and parliament as well. Otherwise recognition as third gender will be of no value. Nonetheless, as the number of eunuch people is few and yet the number is undetected that's why keeping a center of attention group for this study was not possible. For future research it is suggested to detect the number of the eunuch people as well as to take into consider the other variables for hampering the right to education of the eunuch people. But further study can also include other variables like parents awareness, monitory condition etc.

\section{CONCLUSION}

Third gender is used to identifying a social status that required showing consistent labeling and other linguistic practices in a society that distinguished a class of individuals from both men and women, and ascribed them with a assemblage of traits comparable to those traits used to define other gender. But for this strange species of humanity, who happen to be eunuchs more by design than by birth or accident and rarely by choice, nothing is what seems to be. When a section of human beings becomes a chestnut of our making, never mind the pressures of our social conditioning, it is time we questioned their claim to be treated only as normal human beings who can love and hate, construct and destroy, as strongly and as powerfully as ordinary mortals can. Bangladesh is not a monolithic country; it is a multi-religion, multilingual, multi-gender and multi-cultural state, prognostic the beauty of democracy. The guarantee of right to education to the Hijras (third gender) may uphold and retain these images of Bangladesh. Otherwise all of these big talks shall be proved mere homily. Without the right to education it will be difficult for them to survive in this country with respect, dignity and generous life. Let's stand up together and make them feel like a part of our world, so that they too can become first class citizens of Bangladesh and not move violently persistently for mere survival. Surely this is not too hard to achieve. Finally it can be said that the situation is changing slowly. Now the people of third gender should be positively welcome in the society so that they can set up their position in the society with honor and respect as human being like us. Last but not the least the government, the civil society and the Non-Governmental Organizations should stand by them through ensuring their rights to education.

\section{REFERENCES}

[1] Emma, W. (1996). Sexuality and the Reading Encounter: Identity and Desire in Proust, Duras, Tournier, and Cixous (ISBN 0-19-815885-8). Oxford: Oxford University Press.

[2] Gedge, K. (2009). Reviews: Transgender History. Choice: Current Reviews for Academic Libraries, 46

[3] Ghiselin, M. T. (1969). The evolution of hermaphroditism among animals. Quarterly Review of Biology, 44 (2): 189-208.

[4] Herculine, B. and Michel, F. (1980). Being the Recently Discovered Memoirs of a Nineteenth-century French Hermaphrodite ( $2^{\text {nd }}$ edition). New York: Pantheon Books.

[5] Jarne, P. and Auld, J. R. (2006). Animals mix it up too: the distribution of self-fertilization among hermaphroditic animals. Evolution 60 (9): 1816-24.

[6] Johanna, O. (2005). Foucault on Freedom ( $2^{\text {nd }}$ edition). Cambridge: Cambridge University Press.

[7] Kelly, R. C. (2009). Moving Across and Beyond Boundaries. Duke University Press, 15 (4): 646-648.

[8] Mckeown, T. (1988). The origin of human disease ( $2^{\text {nd }}$ edition). Blackwell Publishers, England.

[9] Meese, E. A. and Parker, A. (1989). The Difference Within: Feminism and Critical Theory . John Benjamins Publishing Company.

[10] Money, J. and Hampson, J. G. (2002). Hermaphroditism: recommendations concerning assignment of sex change of sex and psychologic management. Bull Johns Hopk Hosp.

[11] Serena, N (1990). Neither Man nor Woman ( $3^{\text {rd }}$ edition). Wadsworth Publishing Company, California.

[12] Warner, R. (1988). Sex change and the size-advantage model. Trends in Ecology and Evolution, 3 (6): 133-136.

[13] Wijngaard, V. D. and Marianne (1997). Reinventing the Sexes: The Biomedical Construction of Femininity and Masculinity. Indiana University Press.

[14] http://www.dhakatribune.com/juris/2015/jan/08/ensure-rights-third-gender (Retrieved on 10.05.2015)

[15] http://www.dhakatribune.com/op-ed/2013/nov/17/third-gender (Retrieved on 12.06.2015)

[16] http://www.dhakatribune.com/law-rights/2014/oct/25/hijras-demand-proper-recognition-thirdgender\#sthash.ELWm4uoz.dpuf (Retrieved on 17.06.2015)

[17] http://en.wikipedia.org/wiki/right_to_education\#cite_note6 (Retrieved on 21.07.2015)

[18] http://www.thedailystar.net/advancement-of-transgender-rights-55529 (Retrieved on 10.08.2015)

[19] http://emmashopebook.com/en/e-book/295334/education-inequality-and-global-justice (Retrieved on 26.08.2015) 